\title{
Gereja Ekstra Biblikal dan Tanggung Jawab dalam Menyelesaikan Amanat Agung
}

\author{
Y. M. Imanuel Sukardi \\ Sekolah Tinggi Theologia Baptis Jakarta \\ ymsukardi@yahoo.com
}

\begin{abstract}
There has emerged a kind of phenomenon of extra-biblical churches in present days. This article is a qualitative study that aimed to explain the phenomenon of the extra-biblical church. By using the descriptive analysis method on the extra-biblical church phenomenon, there are some findings concluded from this study, namely: First, the extra-biblical church is a church whose existence and legitimacy exceeds Bible standards, its pattern and behavior exceeds the demands of the Bible. Secondly, the extra-biblical church legitimized by tradition, traditional and traditional forms have several deadly good traditions such as the tradition of growth not multiplication, the tradition of teaching not obedience, the tradition of service in not outreach and so on; Third, the extra-biblical church is oriented and has a mega church structure that is so complex and very expensive that it is difficult to duplicate and multiply. As a result, there is a decrease in intensity in carrying out the grand mandate.
\end{abstract}

Keywords: church; extra-biblical; great comission

\begin{abstract}
Abstrak
Belakangan ini muncul semacam fenomena gereja ekstra biblikal. Ini merupakan kajian kualitatif yang bertujuan untuk menjelaskan fenomena gereja ekstra biblikal tersebut. Dengan menggunakan metode analisis deskriptif pada fenomena gereja ekstra biblikal tersebut, ada beberapa kesimpulan yang didapat dari kajian ini, yakni: Pertama, gereja ekstra biblikal adalah gereja yang eksistensi dan legitimasinya melebihi standar Alkitab, pola dan perilakunya melampaui tuntutan Alkitab. Kedua, gereja ekstra biblika dilegitimasi oleh tradisi, berpaham dan berbentuk tradisional memiliki beberapa tradisi baik yang mematikan seperti tradisi pertumbuhan bukan pelipatgandaan, tradisi pengajaran bukan ketaatan, tradisi pelayanan ke dalam bukan penjangkauan ke luar dan sebagainaya; Ketiga, gereja ekstra biblika berorentasi dan berstruktur gereja mega yag begitu rumit dan sangat mahal sehingga sulit diduplikasi dan dimultiplikasi. Akibatnya, terjadi penurunan intensitas dalam melakukan amanat agung.
\end{abstract}

Kata Kunci: amanat agung; ekstra biblikal; gereja

\section{PENDAHULUAN}

Dua pilar utama kehidupan gereja adalah Syahadat Agung dan Mandat Agung. Syahadat Agung berisikan mengasihi Allah dan mengasihi sesama (Mat. 22:37-39), Mandat Agung sebuah amanat untuk menjadikan semua bangsa murid Kristus (Mat. 28:19-20). 
Kedua pilar tersebut saling menentukan tidak bisa dipisahkan satu sama lain. "Jika kamu mengasihi Aku, kamu akan menuruti segala perintah Ku" (Yoh. 14:15). Kasih dan ketaatan identik dengan representasi esensi dan eksistensi gereja. "Ketaatan adalah satu-satunya modus mengasihi Allah tidak ada yang lain, tidak bisa ditukar dan tidak bisa ditunda. Jika mengasihi maka menaati". ${ }^{1}$ Kristus menempatkan ketaatan terhadap Amanat Agung pada tingkat urgensi tertinggi dan segera (bnd. Mat. 28:16-20). "Yesus menanamkan ke dalam gereja mula-mula sebuah keharusan dari setiap orang secara alami mengalir panggilan memproklamasikan Injil Allah" (bdk. KPR. 1:8). ${ }^{2}$ Sebuah hasil survei dalam kaitannya antara kasih dan panggilan tersebut menunjukkan "Gereja yang bertumbuh rata-rata memiliki kasih yang lebih tinggi dibandingkan gereja yang mandek atau menurun."3

Kasih dan ketaatan, ketaatan terhadap Amanat Agung cenderung diabaikan oleh gereja sejak zaman Kaisar Konstantin sampai saat ini. Gereja di era tersebut berbeda dengan era generasi sebelumnya. "Gereja generasi kedua dan ketiga ini lebih sehat, lebih reproduksi, lebih besar kerinduannya untuk menjangkau sisa dunia lainnya dengan Kabar Baik, berbanding terbalik dengan gereja setelahnya." ${ }^{4}$ Kesimpulan tersebut didukung fakta bahwa selama Amanat Agung dipercayakan terhadap gereja sejak zaman kekaisaran Konstantin abad 4 sampai sekarang belum mendekati penyelesain. "Gereja tidak mengalami gerakan selama 1200 tahun, pada abad 19 pernah terjadi 2 gerakan, abad 20 mengalami 11 gerakan, pada tahun 2000-2012 terjadi 69 gerakan, dan semua gerakan tersebut terjadi di luar prakarsa gereja."5

Gereja dalam perkembangannya sejak diresmikannya sebagai agama negara pada abad keempat masa kekuasaan Konstantin sampai saat ini menunjukkan telah mengalami perubahan drastis menjadi gereja ekstra biblika. Keberadaan gereja yang demikian memiliki implikasi langsung terhadap penyelesaian Amanat Agung.

\section{Gereja Ekstra Biblika Versus Standar Alkitab}

Secara sederhana, yang dimaksud dengan gereja ekstra biblika adalah gereja yang melampaui standar Alkitab. Billy Graham berpendapat tentang gereja generasi sekarang, "Iklim yang mewarnai institusi gereja masa kini tampaknya sedang menyeret gereja ke dalam keadaan yang sangat membahayakan...Kalau tidak segera diadakan pembenahan...gereja akan terus mengalami kemunduran." ${ }^{\text {"6 }}$ Rick Warren menegaskan "Saya percaya

${ }^{1}$ Imanuel Sukardi, Strategi Penanaman Gereja Ekspansional (Jakarta: STT Baptis Jakarta), 8.

${ }^{2}$ David Garrison, Church Planting Movement: How God Redeeming a Lost World, WIG Take Resources, 203.

${ }^{3}$ Christian A. Schwarz, Pertumbuhan Gereja yang Alamiah (Jakarta: Metanoia), 36.

${ }^{4}$ Neil Cole, Organic Church (Yogyakarta: Andi), 43.

${ }^{5}$ Kevin J. Humble, Bahan Pelatihan Disciple Making Movement, t.th.

${ }^{6}$ Darrel W. Robinson, Total Church Life (Bandung: Lembaga Literatur Baptis), XIII. 
bahwa persoalan utama gereja abad 21 ini ialah "kesehatan" gereja, bukan pertumbuhan gereja." 7

Bagian paling sulit dari doktrin gereja adalah menghilangkan salah paham dan citracitra mental buruk yang telah melandanya. Kita perlu membersihkan pikiran kita dan mulai lagi dengan membiarkan Alkitab dan Roh Kudus menafsirkannya untuk kita. ${ }^{8}$ Istilah yang dipakai Alkitab untuk gereja atau jemaat adalah terjemahan dari kata "ekklesia". Kata ini berasal dari dua kata: ek yang berarti dari, dan klesis, yang berarti sebuah panggilan. Ini menunjuk kepada orang-orang yang dipanggil untuk berkumpul. Kata ini tidak merujuk pada sebuah gedung, melainkan kepada sebuah kelompok orang yang khusus berkumpul untuk sebuah maksud tertentu. Ini merupakan kumpulan orang-orang kudus. ${ }^{9}$

Gereja standar Alkitab adalah gereja yang memenuhi dan tidak melampaui apa yang telah ditetapkan Alkitab bagi gereja secara khusus dari segi esensi dan eksistensinya. Gereja dari segi esensi adalah dianalogikan tubuh Kristus yang beranggotakan terdiri dari murid-murid Kristus di setiap tempat di sepanjang zaman yang telah mengalami pertobatan dan perpalingan kepada Kristus hidup berbasis ketaatan dan berpusatkan kepada Kristus. "Salah satu gambaran Perjanjian Baru yang paling berkuasa dan mendalam yang diberikan tentang gereja adalah sebagai tubuh Kristus." ${ }^{10}$ Gereja sebagai tubuh Kristus sesungguhnya bukan sekedar analogi yang telah menjadi dogma melainkan dogma berdasarkan fakta, fakta yang telah menjadi dogma (bdk. 1 Kor. 10:16-17; 12:12-14; Ef. 1:23; Kol. 1:18). "Kita sekarang adalah tubuh-Nya di dunia.",11

Gereja sebagai tubuh Kristus dimana Kristus sebagai kepala memiliki konsekuensi logis di antaranya gereja tidak bisa memiliki kehidupan dan tujuan sendiri. "Misi Tuhan Yesus dalam dunia adalah menyelamatkan yang tersesat. Jika gereja adalah tubuh Kristus, Dia hidup di dalamnya. Misi-Nya menjadi misi kita juga. Detak jantung Tuhan Yesus menjadi detak jantung kita juga." "12 Gereja dipandang dari segi eksistensi, Kristus sebagai pendiri, pondasi dan pemilik gereja. "...di atas batu karang ini Aku akan mendirikan jemaat$\mathrm{Ku}$ dan alam maut tidak akan menguasainya" (Mat. 16:18) "Ini adalah tempat yang benar untuk memulai jika kita berbicara tentang apakah gereja itu sesungguhnya."13 Konsep gereja yang benar diawali dan dikembangkan berdasarkan pernyataan Yesus bahwa Dia adalah Inisiator, Konseptor, Investor dengan sendirinya sebagai Protektor dan Regulator gereja.

\footnotetext{
${ }^{7}$ Rick Warren, The Purpose Driven Church (Grand Rapid, Zondervan Publishing House), 17.

${ }^{8}$ Michael Griffths, Gereja Dan Panggilannya (Jakarta: BPK Gunung Mulia), 2.

${ }^{9}$ Dick Iverson, Larry Asplund, Gereja Sehat dan Bertumbuh (Malang: Gandum Mas), 174.

${ }^{10}$ Ibid, 163.

${ }^{11}$ Paul W. Powell, The Church Today, Annuity Board, 41.

${ }^{12}$ Darrel W. Robinson, Total Church Life, 40-41.

${ }^{13}$ Neil Cole, Organic Church, 7.
} 
"Kristus adalah penggagas dan pendiri gereja seperti yang Ia katakan sendiri." 14 Perintis dan pendiri gereja adalah Kristus. Kebenaran Kristus pendiri gereja memastikan rencana Allah bagi gereja dan tujuan Allah melalui gereja. "Tujuan utama gereja dalam kaitannya dengan dunia adalah penginjilan."15 Oleh sebabnya, maka "Kehilangan tujuan menyebabkan gereja kehilangan vitalitas dan sering mati." ${ }^{16}$ Kristus adalah pondasi gereja. Gereja dalam pernyataan Yesus direncanakan dibangun di atas petra, bukan petros. Petra di sini jika dikaitkan dengan pernyataan Paulus dalam 1 Korintus 3:11, maka dapat disimpulkan bahwa petra yang dimaksud oleh Yesus adalah diriNya sendiri. Kristus sebagai pondasi gereja memastikan kekuatan, ketahanan dan kelangsungan gereja yang berpusatkan kepada Kristus (bdk. Ef. 2:21). Gereja yang kuat, kokoh tidak akan runtuh oleh apapun sedang dibangun oleh Kristus.

Gagasan tentang gereja yang dikembangkan para pemikir Kristen sering tidak sesuai dengan fakta bahwa pendiri dan pondasi gereja adalah Kristus sehingga gereja terkesan bersifat desentralisasi dan terancam. Pernyataan Charles Van Engen salah satu contoh, “di seluruh dunia gereja ditanam kecil dan lemah, bertumbuh menjadi tempat perlindungan, kehidupan baru, sehat dan kepenuhan gizi makanan rohani."17 George W. Peters sependapat dengan berkata "ini akan dijadikan catatan bahwa kata eklesia menunjuk kumpulan orang-orang percaya sebagai tubuh lokal atau gereja lokal..."18 Dua tokoh tersebut mewakili pendapat yang cenderung berhaluan desentralisasi gereja dengan dalih membedakan dua macam gereja, lokal dan universal.

Kristus adalah pemilik gereja. "Yesus membeli gereja dengan darah-Nya sendiri (Kis. 20:28). Dia tidak menjanjikan bahwa Dia "akan membangun gerejamu." Gereja adalah milik Yesus. Dia sedang membangun gereja-Nya." ${ }^{19}$ Kristus pemilik gereja memberi ketegasan jaminan pemeliharaan dan perlindungan Kristus terhadap gereja-Nya, perlindungan tanpa batas sehingga alam maut tidak bisa mengalahkan. Kristus pemilik gereja berotoritas sebagai pemberi regulasi terhadap gereja-Nya. Kristus membuat beberapa regulasi berkenaan dengan ibadah. Ibadah gereja berbasis subtansi bukan jumlah. "Sebab di mana dua atau tiga orang berkumpul dalam nama-Ku, di situ Aku ada di tengah-tengah mereka" (Mat. 18:20). Gereja orisinil sesuai standar Alkitab beribadah berdasarkan subtansi, dalam nama Yesus dan penyembahan kepada Allah bukan jumlah, tidak salah dalam jumlah kecil dan tidak salah dalam jumlah besar. Christian A. Schwarz menambahkan "Apakah ibadah merupakan pengalaman yang membangkitkan inspirari bagi

\footnotetext{
${ }^{14}$ Imanuel Sukardi, Pedoman Penanaman Gereja Baru Masa Kini (Surakarta: STT Berita Hidup), 2.

${ }^{15}$ Robert L. Saucy, The Church in God's Program (Chicago: Moody Press), 91.

${ }^{16}$ Linus J. Morris, The High Impact Church (Christian Assosiates Internasional), 130.

${ }^{17}$ Charlen Van Engen, God's Missionary People (Grand Rapid: Baker Books), 26.

${ }^{18}$ George W. Peters, A. Biblical Theology of Missions (Chicago: Moody Bible Institute), 201.

${ }^{19}$ Neil Cole, Organic Church, 8.
} 
anggota jemaat."20 Ibadah yang dibenarkan menurut Alkitab tidak berdasarkan jumlah peserta melainkan subtansinya.

Kristus juga menegaskan bahwa ibadah tidak terikat oleh tempat: "Tetapi saatnya akan datang dan sudah tiba sekarang, bahwa penyembah-penyembah benar akan menyembah Bapa dalam roh dan kebenaran; sebab Bapa menghendaki penyembahpenyembah demikian. Allah itu Roh dan barang siapa menyembah Dia, menyembah-Nya dalam roh dan kebenaran" (Yoh. 4:23-24). Ibadah yang sah tidak ditentukan oleh tempat dan formalitasnya tetapi oleh karakteristiknya, dalam roh dan kebenaran, tidak salah dilaksanakan ditempat dan cara formal, tidak salah dilakukan di tempat dan cara non formal. Ibadah yang dicontohkan gereja mula-mula dalam Kisah Para Rasul tidak menunjukan formalitasnya melainkan karakteristiknya. ${ }^{21}$ "Orang-orang percaya perjanjian baru berkumpul besar-besaran di Bait Allah dan dalam kelompok-kelompok kecil di rumah-rumah keluarga.",22

Gereja diregulasikan pergi $\boldsymbol{k e}$ luar untuk menjangkau seluruh dunia. ${ }^{23}$ Hal ini seperti yang diungkapkan oleh Matius 28:19-20, "Karena itu pergilah, jadikanlah semua bangsa murid-Ku, dan baptislah dalam nama Bapa dan Anak dan Roh Kudus, dan ajarlah mereka melakukan segala sesuatu yang telah Kuperintahkan kepadamu." Regulasi pergi keluar bagi gereja ditanamkan dari dalam bentuk DNA ketika pemuridan sampai dalam bentuk perintah verbal ketika gereja mulai terbentuk formulasinya. "Tetapi kamu akan menerima kuasa, kalau Roh Kudus turun ke atas kamu, dan kamu akan menjadi saksi-Ku di Yerusalem dan di seluruh Yudea, dan Samaria dan sampai ke ujung bumi” (Kis. 1:8) Regulasi tersebut sejalan dengan tujuan Yesus datang ke dunia yang telah diamanatkan kepada gereja. Ini adalah tugas kewajiban misioner gereja yang berasal dari kasih Allah dalam hubungannya yang aktip dengan umat-Nya. ${ }^{24}$ Oleh karena Allah telah mengirimkan Anak-Nya, Yesus Kristus, untuk mencari dan, mengumpulkan, serta mengubah semua orang terasing karena dosa. Dari pengertian ini misi merupakan bagian dari maksud dan tujuan gereja. ${ }^{25}$

Gereja standar Alkitab bisa disimpulkan sebagai berikut: 1) Gereja adalah persekutuan dalam Kristus beranggotakan murid-murid Kristus di setiap tempat

${ }^{20}$ Christian A. Schwarz dan Christoph Schalk, Pertumbuhan Gereja Alamiah, Metanonia, 86.

${ }^{21}$ Harls Evan R. Siahaan, "Karakteristik Pentakostalisme Menurut Kisah Para Rasul," DUNAMIS:

Jurnal Teologi dan Pendidikan Kristiani 2, no. 1 (2017): 12-28, www.sttintheos.ac.id/ejournal/index.php/dunamis.

${ }^{22}$ Dick Inverson, Larry Asplund, Gereja Sehat dan Bertumbuh, 183.

${ }^{23}$ Ibelala Gea, "Beritakan Injil Kepada Segala Makhluk," BIA': Jurnal Teologi dan Pendidikan Kristen Kontekstual 1, no. 1 (2018): 56-69, http://www.jurnalbia.com/index.php/bia/article/view/19.

${ }^{24}$ Halim Wiryadinata, "Mission And Evangelism : African Context," KURIOS (Jurnal Teologi dan Pendidikan Agama Kristen) 3, no. 1 (2015): 63-64, http://www.sttpb.ac.id/e-journal/index.php/kurios.

${ }^{25}$ Thomas E. Norman, Teks-Teks Klasik Tentang Misi dan Kekristenan Sedunia (Jakarta: BPK Gunung Mulia), 147. 
disepanjang jaman setelah mengalami pertobatan dari dosa dan perpalingan kepada Kristus hidup berbasis ketaatan dan berpusatkan kepada Kristus sebagai kepala; 2) Gereja bersifat organisme yang melakukan pertemuan-pertemuan ibadah secara tertib dan teratur dalam kelompok besar maupun kelompok kecil dilaksanakan di tempat dan cara formal maupun non formal; 3) Gereja ditetapkan berorentasi pergi ke luar menjadikan sisa suku bangsa murid Kristus.

\section{PEMBAHASAN}

\section{Gereja Melampaui Standar Alkitab}

Gereja melampaui standar Alkitab adalah gereja ekstra biblika di mana pola, praktik dan perilaku melebihi yang dituntut Alkitab. "Gereja secara praktis atau secara teknis dibedakan menjadi dua jenis: gereja tradisional dan gereja gerakan." 26 Gereja telah mengalami polarisasi secara diam-diam tetapi tajam antara gereja tradisional diwakili oleh gereja ekstra biblika sedang gereja gerakan diwakili oleh gereja standar Alkitab.

Gereja ekstra biblika diidentikkan dengan gereja tradisional karena berbaku pada tradisi. Ditilik dari sudut pandang dogma banyak yang tetap berpegang konsep Alkitab, tetapi pola, praktik dan perilaku lebih tradisional dari pada biblikal. Tradisi diberi kewibawaan tinggi, kewibawaan tradisi dipegang dan dijaga lebh tinggi dari pada kewibawaan Alkitab sehingga terjadi fragmentasi berbasis tradisi dalam kekristenan. Michael Griffiths berpendapat sebagai berikut:

Berbagai kelompok Kristen mengembangkan kebiasaan yang berbeda-beda. Kemudian mereka jadi curiga akan tradisi yang berbeda dari tradisi mereka sendiri dan enggan untuk menerimanya. Dan sebaliknya ini kemudian menjadi suatu hambatan manusia menuju persaudaraan dan kesatuan. ${ }^{27}$

Gereja tradisional yang dimaksud adalah sama seperti dengan apa yang dipahami dan diakui masyarakat Kristen pada umumnya selama ini, "ada gedung, ada struktur organisasi, ada sekelompok besar orang dan infrastruktur lainnya." 28 Gereja tersebut menambahkan dan mengembangkan apa yang tidak dituntut oleh Alkitab seperti: struktur organisasi, denominasi, liturgi, legalisasi, sentralisasi "ditambah gedung ditambah pendeta ditambah gaji ditambah program." ${ }^{29}$ David Hunt mendeskripsikan sebagai berikut:

Mereka mengumpulkan sumber daya finansial, mengangkat pemimpin karismatik, menetapkan struktur organisasi, pengamanan aset, sebuah kontruksi bangunan, dan sebuah inisiatif program pemasaran untuk menarik orang-orang masuk ke dalam gedung gereja untuk mengikuti berbagai variasi program dan kegiatan.",30

\footnotetext{
${ }^{26}$ David Garrison, Church Planting Moovement (Ricmond: IMB), 194.

${ }^{27}$ Michael Griffiths, Gereja dan Panggilannnya Dewasa ini, 109.

${ }^{28}$ Sukardi, Strategi Penanaman Gereja Ekspansional, 47.

${ }^{29}$ Wolfgang Simson, Gereja Rumah Mengubah Dunia (Jakarta: Metanoia Publishing), 43.

${ }^{30}$ David Hunt, A Revolution in Church Multiplication in East Afrika, www.davidlwatson.org. Penelusuran 18 April 2017.
} 
Gereja tradisional berorentasi yang tidak diorentasikan Alkitab di antaranya: orentasi keanggotaan bukan pemuridan, orentasi pelayanan ke dalam bukan pergi keluar, orentasi pada organisasi bukan organisme, orentasi pada program kegiatan bukan hubungan, orentasi pada gereja mega bukan gereja banyak, orentasi pada pengajaran bukan ketaatan, orentasi pada apa yang bisa dilakukan bukan apa yang perlu dilakukan.

Gereja yang tidak bertanya "Tuhan, apa yang Engkau mau kami lakukan?"31 dan tidak melihat perubahan yang sedang terjadi. "Gereja sedang berubah dari struktur "datang" menjadi berstruktur "pergi",32, dari fokus pada hasil yang telah dicapai ke "fokus pada hasil yang lebih besar" ${ }^{\prime 3}$ Semua penjelasan di atas tetap berlaku bagi gereja tradisional sampai saat ini, beberapa di antaranya atau hampir semuanya telah dijadikan standar primer dan mutlak sehingga gereja tradisional menjadi sangat rumit, sangat mahal, sangat komplek, sangat eksklusif dan sangat akaliah. Keberadaan gereja tradisonal sebagaimana tersebut membuat sulit dimultiplikasi, sulit diduplikasi, sulit didekati dan sulit diubah. Karena "ketika gereja menjadi begitu rumit, fungsinya dicabut dari tangan orang kristen biasa dan ditempatkan dalam tangan beberapa profesional berbakat."34

Paham dan ajaran yang dianut oleh gereja jenis ekstra biblika sering lebih mudah ditemukan dari dalam tradisi dan latar belakangnya dari pada dalam Alkitab, "bahkan mereka mengasihi tradisi mereka lebih dari pada mereka mengasihi masyarakat setempat." 35 Doktrin mereka yang paling tepat adalah yang merupakan bagian dari apa yang dikatakan Alkitab, dan yang paling buruk adalah yang mengandung ajaran dan praktik-praktik ekstra alkitabiah berdasarkan sejarah gereja mereka. Semua gaya pemujaan, gaya kepemimpinan, gaya tata kelola kebanyakan bersifat ekstra alkitabiah, walaupun semua denominasi akan mengklaim bahwa latar belakang praktik mereka adalah alkitabiah."36

Gereja standar Alkitab jauh lebih sehat dari pada gereja ekstra biblikal. Karena "diukur berdasarkan standar Alkitab dengan acuhan keberadaan dan kehidupan gereja mula-mula, bukan besarnya gedung dan banyaknya pengunjung." "37 Praktik dan perilaku kedua gereja tersebut cenderung berlawanan arah. Gereja standar Alkitab lebih hidup, lebih dinamis, lebih praktis, lebih fellowship dan lebih mudah bergerak berbeda dengan gereja ekstra biblika lebih menyukai kemapanan, menolak perubahan, cenderung kaku, tertutup,

\footnotetext{
${ }^{31}$ Darrell W. Robinson, Total Church Life, 16.

${ }^{32}$ Simson, Gereja Rumah Mengubah Dunia, th, tesis 11.

${ }^{33}$ Sukardi, Strategi Penanaman Gereja Ekspansional, 83.

${ }^{34}$ Coel, Organic Church, 27.

${ }^{35}$ Hunter, Church for Churched, 59.

${ }^{36}$ Imanuel Sukardi, Kajian Teologis Terhadap New Disciple Making Movement Berdassarkan Matius 28:19-20 Dan Relevansinya Terhadap Penanaman Gereja Masa Kini, (Disertasi D. Th. STT Berita Hidup,

${ }^{37}$ Wolfgang Simson, Gereja Rumah yang Mengubah Dunia, Metanoia Publishing, 2003, 95.
} 2017), 276 
lebih kompleks dan lamban. Gereja yang didorong oleh tradisi ungkapan kesayangannya adalah "Kami selalu melakukannya begitu." Gereja yang didorong oleh tradisi adalah mengabadikan masa lalu. Perubahan selalu dilihat sebagai hal yang negatif, dan stagnasi selalu ditafsirkan sebagai stabilitas.",38

Gereja ekstra bibilika bisa disimpulkan sebagai berikut: 1) Gereja ekstra biblika secara teologis, konsep dan paham tentang gereja banyak yang Alkitabiah; 2) Gereja ekstra biblika ditinjau dari segi pola, praktik dan perilaku lebih berbasis tradisi dari pada Alkitab; 3) Gereja ekstra biblika berorentasi ke dalam, ke mega gereja, ke organisasi atau denominasi, ke legalistik dan sentralistik; 4) Gereja ekstra biblika menjadi rumit dan mahal sehingga sulit diduplikasi dan dimultiplikasi.

\section{Implikasi Terhadap Penyelesaian Amanat Agung}

Kristus sebagai pendiri, pondasi dan pemilik gereja sekaligus pemberi amanat terhadapnya, yang dinyatakan dalam Matius 28:19-20, dipastikan gereja dituntut bertanggungjawab terhadap penyelesaian amanat tersebut. Gereja memiliki tujuan yang dinyatakan dalam Matius 28:19-20, ayat yang dikenal sebagai Amanat Agung, perintah ini berhubungan dengan perintah Allah yang terpenting, yakni menjadikan semua bangsa umat pilihan. $^{39}$

Gereja yang telah beranjak dari standar Alkitab menjadi ekstra biblika, akhirnya menunjukkan arah terbalik dari arah yang telah ditetapkan untuk menyelesaikan Amanat Agung. Sejarah gereja yang tidak pernah mengungkapkan kegagalan dalam pencapaian Amanat Agung. Gereja tradisional sejak memakai "pendekatan secara denominasional dalam mengerjakan Amanat Agung belum berhasil meskipun sudah dilakukan selama 1600 tahun atau 492 tahun sejak reformasi Protestan yang dimulai tahun 1571."40 Michael Griffiths mempertegas kondisi tersebut dengan mengatakan, "Tidak diragukan lagi bahwa gereja merupakan rintangan terbesar untuk menginjili dunia."

\section{Menghentikan Amanat Agung Secara Sistematis}

Gereja-gereja ekstra biblika sendiri tentu tidak bisa menerima kategori dan predikat yang diberikan kepadanya sebagai gereja ekstra biblika dan penghenti Amanat Agung. John Cambell pernah merilis hasil penilaian terhadap gereja terkait judul di atas. Dalam penelitian di Skotlandia bertema penghalang-penghalang untuk percaya tahun 1994, ia

\footnotetext{
${ }^{38}$ Rick Warren, Purpose Driven Church, 83.

${ }^{39}$ Ron Jenson dan Jim Steven, Dinamika Pertumbuhan Gereja, Malang: Gandum Mas, 55.

${ }^{40}$ Imanuel Sukardi, Kajian Teologis Terhadap Disciple Making Movement Berdasarkan Matius 28:19-20 (Disertasi), 275.

${ }^{41}$ Michael Griffiths, Gereja Dan Pelayanannya, VII.
} 
berkata, "Banyak orang telah mengindikasikan bahwa salah satu penghalang terbesar bagi seseorang untuk percaya kepada Kristus adalah gereja mereka sendiri."

Gereja-gereja ekstra biblika atau tradisional memiliki dan memegang kuat beberapa tradisi baik namun mematikan Amanat Agung secara sistematis. Tradisi-tradisi yang dimaksud adalah sebagai berikut:

\section{Tradisi ke Dalam Bukan ke Luar}

Gereja yang benar dimulai dari pergi ke luar menjangkau yang belum terjangkau. Gereja yang diawali dengan benar tersebut sering tidak diahiri dengan benar, karena akhirnya fokus pelayanan ke dalam kepada orang-orang yang telah dikumpulkan dalam struktur bangunan yang dimaknai sebagai gereja. Pelayanan terhadap orang-orang dalam tidak bisa diabaikan tetapi jika telah menggantikan penginjilan ke luar, maka telah mematikan gerakan Amanat Agung dan itu yang terjadi. Banyak gereja dimulai dengan pergi ke sebuah komunitas baru, namun kemudian mendirikan sebuah bangunan untuk orang-orang "datang ke" untuk menemukan Tuhan atau komunitas atau...Anda mengisi kekosongan itu. ${ }^{43}$

Gereja yang fokus ke dalam, menciptakan berbagai program kegiatan untuk menarik orang-orang masuk ke dalam dan untuk mempertahankan orang-orang tetap di dalam telah menghentikan Amanat Agung dengan sendirinya. "Jika gereja berhenti menjangkau ke luar ke semua orang, ini berarti telah berhenti menjadi gereja yang benar. Ini adalah alasan mengapa Amanat Agung mengontrol dan tetap menjadi perintah pertama."44 Pelayanan terhadap orang-orang yang telah masuk ke dalam merupakan sebuah tradisi yang baik tetapi ketika telah menggantikan pergi ke luar menjangkau yang tersisa, tradisi tersebut telah mematikan Amanat Agung.

Gereja yang fokus ke dalam, akan memusatkan dan menghabiskan energi dan sumber daya untuk pelayanan ke dalam, bahkan semua kekuatan dan kekayaan difokuskan untuk acara dua jam ibadah hari minggu, sehingga tidak tersisa untuk usaha penginjilan. Keuangan yang ada dipusatkan untuk menutup semua kebutuhan operasional dan gaji para profesional akibatnya alokasi dana penginjilan ditiadakan. Selain pelayanan ke dalam menjauhkan gereja dari gerakan penginjilan, masalah keuangan pun tidak kalah kuatnya. Gereja lokal akan menghadapi banyak masalah keuangan atau pendanaan yang menyebabkan tidak sanggup melakukan gerakan penginjlan. ${ }^{45}$

\footnotetext{
${ }^{42}$ Simson, Gereja Rumah Mengubah Dunia, 13.

${ }^{43}$ David L. Watson, Church Planting Essensial-Four Ways to Kill Church Planting,www. davidlwatson.org. Penelusuran 25 April 2017.

${ }^{44}$ Edward R. Dayton dan David A, Fraser, Planing Strategies for World Evangelization (Grand Rapids: Wm. B. Eerdmans), 45.

${ }^{45}$ Imanuel Sukardi, Strategi Penanaman Gereja Ekspansional, 49.
} 
Gereja ekstra biblika bertradisikan menggantikan pelayanan penjangkau ke luar dengan pelayanan pemeliharan ke dalam, memusatkan dan menghabiskan seluruh sumberdaya untuk pelayanan ke dalam, pada saat itu gereja telah mematikan Amanat Agung. Karena "Amanat Agung adalah mandat untuk pergi." "46 Gereja di seluruh dunia menunjukkan kesibukannya ke dalam telah menggantikan kewajibannya menjangkau ke luar baik secara personal, operasional dan finansial sehingga berkategori penghenti Amanat Agung.

\section{Tradisi Pertumbuhan Bukan Pelipatgandaan}

Pertumbuhan dua tradisi yang berbeda. Pertumbuhan adalah paradigma gereja berhaluan tradisional yang berorentasi membangun mega gereja, sedang pelipatgandaan merupakan paradigma gereja gerakan dengan misi mendirikan banyak gereja. Paradigma reproduksi berkecepatan tinggi berdiri berada dalam perbedaan yang tajam dengan pandangan kebanyakan gereja tradisonal yang berpandangan bahwa, gereja pertama harus bertumbuh menjadi besar dulu dan cukup dewasa untuk bisa ambil bagian pengorbanan bersama dalam usaha pekerjan baru. ${ }^{47}$

Gereja tradisional berorientasi pertumbuhan menempatkan mega gereja menjadi tujuan utama. Pelipatgandaan penanaman gereja baru yang berkelanjutan bukan ide yang dicari dan bukan usaha yang sanggub dilakukan. Gereja berstruktur mega gereja paling tidak memungkinkan menyelesaikan Amanat Agung karena tingkat kerumitan dan kemahalannya yang terlalu tinggi. "Struktur gereja sel adalah cara yang lebih efektip untuk menyelesaikan suku-suku yang berbeda dan jaringan kota, sebuah kemampuan yang tidak dimiliki gereja mega." 48

Gereja mega tidak semurah dan semudah gereja biblika sehingga sulit diduplikasi dan dimultiplikasi. Alasan lain, membangun gereja mega menyita segenap eksistensi dan konsentrasi, menciptakan banyak sekali pelayanan dan kebutuhan yang perlu dipenuhi sehingga tidak memiliki kesanggupan dan tidak ada agenda untuk Amanat Agung. Jika mega gereja menjadi tujuan, maka penanaman gereja baru dihentikan dan Amanat Agung dimatikan dengan sendirinya. Jeffry Quester berpendapat: Dari sudut pandang strategis gereja berukuran raksasa dan berukuran rata-rata tidak akan pernah memenuhi Amanat Agung tanpa ada rencana dan tujuan untuk meluncurkan ribuan jemaat kelinci. Hanya jemaat kelinci yang memiliki kemampuan berproduksi lebih cepat. ${ }^{49}$

Cara satu-satunya yang dipahami untuk menjadi mega gereja adalah melalui pertumbuhan. Pertumbuhan dengan penambahan dari peranakan Kristen baru, perpindahan

\footnotetext{
${ }^{46}$ Tom Rhainer, Effective Evangelistic Church (Nashville: Broadman and Holman Publisher), 19.

${ }^{47}$ David Garrison, Church Planting Movement, 195.

${ }^{48}$ Linus Moris, High Impact Curch, International Christian Assosiate, 22.

${ }^{49}$ Jeffry Quester, Gerakan Allah Pada Masa Kini, 142.
} 
Kristen baru dan pemeluk Kristen baru tidak akan pernah menyelesaikan Amanat Agung. Paradigma pertumbuhan indikator gereja tidak sehat karena diukur berapa besar gedung dan berapa banyak pengunjung. "Salah satu pertanyaan yang harus kita ajukan untuk mengevaluasi kesehatan gereja ialah: berapa banyak orang yang digerakkan untuk melaksanakan Amanat Agung." "50 Karena menjangkau suku-suku belum terjangkau sebagaimana diperintahkan dalam Amanat Agung tidak bisa dengan cara pertumbuhan melalui penambahan.

Tradisi pertumbuhan bertujuan gereja mega berdalih pengutusan dalam melaksanakan Amanat Agung. Amanat Agung tidak bisa diselesaikan melalui pengutusan karena pengutusan sangat terbatas. Gereja pertama menentukan gereja berikutnya, gereja mega akan mendirikan gereja mega. "Suatu model yang diperkenalkan di daerah tertentu adalah sebuah model dimana sebuah gereja lokal yang mengutus, mendukung dan mengawasi para misionarinya tanpa bantuan suatu apapun dari luar."51 Pertanyaannya berapa gereja mega sanggup didirikan dan berapa gereja mega sanggup mendirikan gereja yang sama? Berapa banyak orang dan berapa lama gereja mega sanggup mengutus? Pelipatgandaan tidak bisa digantikan pengutusan dalam penyelesaian Amanat Agung. Karena gereja sendiri adalah misi, ia tidak akan mengutus utusan khusus dan sejenisnya. Ia mengutus dirinya sendiri dalam unit-unit yang dapat bermultiplikasi, unit-unit embrio yang terdiri dari dua atau tiga orang. ${ }^{52}$

Pertumbuhan menuju gereja mega adalah tradisi baik yang mematikan Amanat Agung karena hanya pelipatgandaan berkelanjutan yang bisa menjawab tantangan Amanat Agung. "Satu-satunya metodologi penginjilan paling efektif di bawah langit adalah penanaman gereja-gereja baru.",53 Metode tersebut telah lama ditinggalkan sejalan ditinggalkannya pendekatan pelipatgandaan oleh gereja.

\section{Tradisi Pengajaran Bukan Ketaatan}

Pengajaran telah menjadi ciri dan tradisi gereja-gereja ekstra biblika. Pengajaran yang dimaksud adalah pengajaran tentang berbagai pengetahuan kepercayaan dan kebenaran Kristen melalui berbagai bentuk ibadah, kuliah, ceramah, seminar dan lain sebagainya. Setiap pertemuan, setiap umur, setiap minggu jemaat mendapatkan pengajaran yang telah diprogram gereja. Sebuah tradisi baik tetapi mematikan karena Amanat Agung menuntut ketaatan segera bukan sekedar pengetahuan luas. Orentasi yang ditinggalkan dan berdampak menyeluruh interen maupun eksteren adalah orentasi ketaatan. "Sekarang ini,

\footnotetext{
${ }^{50}$ Rick Warren, Purpose Driven Church, 37.

${ }^{51}$ Dean Wiebracth, Menjawab Tantangan Amanat Agung, Yogyakarta: Yayasan Andi, 217.

${ }^{52}$ Wolfgang Simson, Gereja Rumah Mengubah Dunia, 53.

${ }^{53}$ Peter Wagner, Penanaman Gereja untuk Tuaian yang Lebih Besar, Jakarta: Harvest Publication House, 13.
} 
jemaat pengikut Isa telah menempatkan sebagian besar fokus mereka pada pengetahuan sedang ketaatan menjadi sesuatu yang sekedar diharapkan terjadi."54

Amanat Yesus berbasis ketaatan: “...ajarlah mereka melakukan segala sesuatu yang telah Ku perintahkan kepadamu...." Amanat Agung hanya bisa diselesaikan melalui ketatan. "Amanat Agung tidak akan pernah diselesaikan oleh orang-orang berpengetahuan, melainkan oleh mereka yang memiliki ketaatan." ${ }^{, 55}$ Pengetahuan tidak bisa menggantikan ketaatan, karena itu pengajaran yang tidak berbasis ketaatan tidak akan menyelesaikan Amanat Agung. Suku-suku yang masih tersisa memerlukan ketaatan segera tanpa ditunda bukan intensitas pengajaran kepercayaan Kristen dalam gedung gereja. "Gereja bisa saja mempunyai doktrin yang benar, tetapi tetap belum menjadi gereja Perjanjian Baru," kecuali memiliki ketaatan menjadikan semua bangsa murid-Nya. ${ }^{56}$ Murid-murid Kristus dan gereja generasi pertama telah membuktikan dua hal: tidak memiliki banyak pengetahuan Alkitab dan paling berhasil dalam mengerjakan Amanat Agung. Mereka adalah orang-orang yang melakukan apa yang mereka tahu.

Menurut survei tidak resmi yang pernah dilakukan oleh seorang utusan Injil di Papua mengatakan, apabila perintah Tuhan dalam Amanat Agung tidak ditaati dalam tempo 48 jam, maka tidak pernah ditaati. Survei yang lain menyatakan, orang-orang Kristen yang paling efektif dan paling banyak memenangkan jiwa bagi Kristus adalah orang-orang Kristen baru yang belum banyak tahu tentang Alkitab, tetapi menaati yang sudah diketahui. $^{57}$

\section{Menghentikan Amanat Agung Secara Masif}

Gereja tradisional bisa dikatakan gereja organisme yang diformulasikan menjadi organisasi yang dipresentasikan dalam bentuk denominasi. Gereja tersebut ketika memberitakan Injil untuk mendirikan gereja baru sesungguhnya lebih dipenuhi hasrat menanam denominasi dari pada mengerjakan Amanat Agung. Herbert Kane bersaksi:

Yang kami lakukan adalah apa yang kami katakan untuk tidak akan kami lakukan; kami mengirim denominasi kami ke ladang misi. Dalam banyak kota besar, kami berakhir dengan 150 misionari di masing-masing masyarakat yang memproduksi gereja atau denominasi yang berbeda-beda, yang hampir dalam banyak hal mirip kembali ke asal dengan gereja induk. Kami tidak cukup mengekspor denominasi kami, kami menyusupkan ke dalam gereja bentuk-bentuk struktur gereja kami yang rumit jauh sebelum mereka mampu bertanggung jawab. ${ }^{58}$

\footnotetext{
${ }^{54}$ Jeffry Quester, Gerakan Allah Pada Masa Kini, 121.

${ }^{55}$ Sukardi, Strategi Penanaman Gereja Ekspansional, 14.

${ }^{56}$ Darrell W. Robinson, Total Church Life, 54.

${ }^{57}$ Sukardi, Strategi Penanaman Gereja Ekspansional, 14.

${ }^{58}$ J. Herbert Kane, Christian Understanding Mission, 352.
} 
Ada praktik yang bisa dicermati, ketika sebuah denominasi berusaha mendirikan gereja baru, Amanat Agung (setidak-tidaknya) bukan alasan utama melainkan sedang berusaha mempertahankan dan memperluas denominasi dengan cara tersebut. Bukti di lapangan membenarkannya, misal ada beberapa denominasi mendirikan gereja baru di area yang sama, yang terjadi tidak saling mendukung melainkan saling bersaing dengan identitas dan kekuatan sendiri-sendiri. Contoh konkrit:

Sementara beberapa denominasi makin surut di Amerika Serikat, denominasidenominasi lain di negara yang sama dalam kurun waktu yang sama bertumbuh pesat. Tanpa pengecualian, denominasi-denominasi yang bertumbuh adalah yang menekankan penanaman gereja. ${ }^{59}$

Denominasi bersifat eksklusif dan kaku karena disandera oleh sejarah, diikat oleh dogma, digerakkan oleh tata cara dan dikendalikan kondisi masing-masing sehingga tidak sedikit di banyak tempat akhirnya tidak mengerjakan Amanat Agung. Fenomena yang cenderung permanen dan konsisten dalam penanaman gereja baru di tempat baru yang dilakukan oleh denominasi tertentu lebih bersifat ekspansional terhadap gereja lama yang sudah ada dari pada menjangkau jiwa baru.

Sudah bukan rahasia lagi bahwa hampir setiap ada perintisan atau pembukaan gereja baru selalu membawa korban gereja lama yang sudah ada. Banyak alasan yang bisa diketengahkan dari yang rasional sampai yang irasional, tetapi tidak bisa menghapus kesan tersebut dengan begitu saja. ${ }^{60}$

Fakta lain memberi indikasi bahwa ketika denominasi mendirikan gereja baru di tempat baru, tidak bisa dihindarkan pada saat yang sama menanamkan budaya, tata cara, gaya hidup, tradisi, nilai-nilai lain yang dibawa dari denominasi asal. Hal tersebut bukan hanya menciptakan lintas budaya bertambah jauh juga menjadi alasan penolakan terhadap Injil oleh masyarakat setempat. "Ketika orang-orang harus meninggalkan nilai-nilai identitas sukunya dan mengangkat budaya lain untuk menjadi orang Kristen," yang di banyak tempat bagi banyak orang beresiko tinggi, menjadi penghalang yang tidak bisa diatasi bagi orangorang yang akan datang kepada Kristus. ${ }^{61}$

Sifat dan tabiat denominasi sebagaimana dijelaskan di atas cepat atau lambat akan menghentikan Amanat Agung secara masif karena kehadiran dan keberadaan di mana berada memiliki kecenderungan yang sama. Jika denominasi tetap bersifat eksklusif dan kaku, bertabiat ekspansional dari pada ekklesial, berhaluan sentra denominasional bukan evangelikal, maka sungguh-sungguh menjadi penghalang Amanat Agung secara masif. Gereja sering menjadi penghalang intern mematikan secara masif.

\footnotetext{
${ }^{59}$ Peter Wagner, Penanaman Gereja untuk Tuaian yang Lebih Besar, 15.

${ }^{60}$ Imanuel Sukardi dan Kevin J, Humble, Pedoman Penanaman Gereja Baru Masa Kini, Solo: STT Berita Hidup, 16.

${ }^{61}$ David Garrison, Church Planting Movement, 66.
} 


\section{KESIMPULAN}

Dari semua penjelasan di atas bisa ditarik beberapa kesimpulan sebagai berikut: Pertama, Gereja yang eksistensi dan legitimasinya melebihi standar Alkitab, pola dan perilakunya melampaui tuntutan Alkitab, masuk dalam kategori ekstra biblika; Kedua, Gereja ekstra biblika dilegitimasi oleh tradisi, berpaham dan berbentuk tradisional memiliki beberapa tradisi baik yang mematikan seperti tradisi pertumbuhan bukan pelipatgandaan, tradisi pengajaran bukan ketaatan, tradisi pelayanan ke dalam bukan penjangkauan ke luar dan sebagainaya; Ketiga, Gereja ekstra biblika berorentasi dan berstruktur gereja mega yag begitu rumit dan sangat mahal sehingga sulit diduplikasi dan dimultiplikasi. Ketiga ciri tersebut dengan sendirinya berimplikasi mematikan Amanat Agung secara sistematis dan masif.

\section{REFERENSI}

Addison, Steve. Movements that Change the World. Mission Press.

Allen ,Roland. Spontaneous Ekspansion of the Church. Grand Rapids: Eerdmans.

Barna, George. Marketing the Churchs: What They Never Taught You about the Church Growth. Colorado Springs: Nav Press, 1988.

Barrett, Lois. Bulding the House Church. Herrald Press.

Coleman, Lyman. Basic Training for Small Group Leaders. Littleton, Colorado:

Serendipity House, 1992.

Cole, Neil. Organic Church: Menghadirkan Gaya Hidup Kerajaan Allah Dalam Gereja. Yogyakarta: Penerbit Andi.

Dayton, Edward R. dan David A. Fraser. Planing Strategies for World Evangelization. Grand Rapids: Wm. B. Eerdmans Co, 1990.

Davis, Anne dan Wade Rowatt, Jr. (ed.). Formation for Christian Ministry. Louissville: Southern Baptis Theological.

Engen, Carles Van. God's Missionary. Grand Rapids, Michigan: Baker Book House.

Erickson, Millard J. Introduction to Christian Doctrine. Grand Rapids, Michigan: Baker Book House.

Faircloth, Samuel D. Church Planting for Reproduction. Grand Rapids: Baker Book House. Garrison David. Church Planting Movements. Ricmond: Internasional Mission Board, 1999.

Gea, Ibelala. "Beritakan Injil Kepada Segala Makhluk.” BIA': Jurnal Teologi dan Pendidikan Kristen Kontekstual 1, no. 1 (2018): 56-69. http://www.jurnalbia.com/index.php/bia/article/view/19.Hunter, George G. Church for the Churched. Nasvile: Abindon Press.

MacArthur, John F. Jr. The Masters Plan for the Church, Chicago: Moody Press, 1991. McGavran Donald. Understanding Church Growth. Grand Rapids: Eerdmans, 1970. Moriis, Linus J. The Hight Impact Church. Internasional Christian Associates. Patterson, George A. Church Planting Through Obedient Oriented Teaching. Pasadena Calf: Willam Cary Libray, 1981. 
Siahaan, Harls Evan R. "Karakteristik Pentakostalisme Menurut Kisah Para Rasul." DUNAMIS: Jurnal Teologi dan Pendidikan Kristiani 2, no. 1 (2017): 12-28. www.sttintheos.ac.id/e-journal/index.php/dunamis.

Sukardi, Imanuel. Pedoman Penanaman Gereja Baru Masa Kini. Surakarta: STT Berita Hidup.

Sukardi, Imanuel. Strategi Penanaman Gereja Ekspansional, Jakarta: STT Baptis Jakarta. Wiryadinata, Halim. "Mission And Evangelism: African Context." KURIOS (Jurnal Teologi dan Pendidikan Agama Kristen) 3, no. 1 (2015): 63-64. http://www.sttpb.ac.id/e-journal/index.php/kurios. 